\title{
Joint Integration of Deng Xiaoping' Reform Theory and Chinese Reform
}

\author{
Wang Guidong \\ Huanggang Normal University, Huang Gang in Hu Bei,438000
}

\begin{abstract}
As one of the theoretical system of socialism with Chinese characteristics, Deng Xiaoping theory provides a strong guiding ideology and driving direction for the development of socialism. The main reform basis of Deng Xiaoping's reform theory is socialistic basic contradictions and the main reform objective is self-improvement and development of socialism. Being one of the main guiding ideology of China's socialist reforms, Deng Xiaoping's reform theory makes an important contribution to frame construction of the theoretical system of socialism with Chinese characteristics and improve the socialist system. The article discusses the close integration of Deng Xiaoping' reform theory and Chinese reform to guide the way forward of construction of socialism with Chinese characteristics by analyzing the process of Deng Xiaoping' reform theory and Chinese reform.
\end{abstract}

Key Words- Deng Xiaoping's reform theory; Chinese reform; Joint integration

\section{INTRODUCTION}

Construction

of socialism with Chinese characteristics is great practical results in the long-term struggle of constructing socialism by the party and state leaders and practical results of theoretical system of socialism with Chinese characteristics. As an important component of Chinese reform system, Deng Xiaoping' reform theory has a strong role in promoting the construction of socialism with Chinese characteristics. It fo- cuses on the main contradictions in the process of construction of socialism with Chinese characteristics and is guided by Chinese opening up policy with a basic goal of self-improvement and development of socialism. And finally it forms a complete set of reform theory in the process of socialism with Chinese characteristics and points the way forward for the construction of socialism with Chinese characteristics. Therefore Chinese reform has a very large correlation with Deng Xiaoping' reform theory.

2. Theoretical basis of reform and establishing socialism with Chinese characteristics

Communists finally established the socialist system through the course of a major new democratic revolution and the socialist revolution in the process of promoting localization of Marxism in China so as to lay the foundation for building socialism with Chinese characteristics and provide a complete theoretical system as well. At the beginning of reform and opening up policy, Deng Xiaoping made detailed analysis and elaborations on contradictions in the process of constructing socialism and formed Deng Xiaoping theory on this basis. China's socialist reform and the establishment socialist system with Chinese characteristics make a good deal with two major contradictions: one is social productivity and productive relation and the other one is the superstructure and the economic base. Deng Xiaoping theory and the reform of Chinese reform are a mutual adaptation.

Deng Xiaoping differs the socialist system from specific systems and make a detailed explanation why lay a solid foundation for social- 
ist system with Chinese characteristics and the socialism reform.

In the beginning of the reform, since the influence of leftist ideas lead to serious negation on socialist system, Deng Xiaoping theory suggests that the socialist system reflects an economy problem from the side. Deng Xiaoping's reform Theory makes overall reform of basic system, which also reflects that Deng Xiaoping theory continues to increase its self understanding and practice reform in the basic socialist contradictions.

\section{Reform and insisting in basic system of social-} ism with Chinese characteristics

Deng Xiaoping's reform Theory first proposes that reform is self-improvement and development of socialism. It points out that the reform should coincide with socialism, unify insisting in and developing socialism, remove defects to achieve self-improvement and finally adhere to the socialist system with Chinese characteristics during the process of reform.

The basic goal of Deng Xiaoping' reform theory is self improvement and development of the socialist system and mainly shows that the basic system of socialism is gradually established in the long struggle by Chinese Communists, which is also in line with Chinese practical conditions and development requirements of productivity as a new system in social progress.

It is the most fundamental to uphold the basic principles of socialism to persist in the direction of socialist system and the socialism in the reform. Deng Xiaoping' reform theory on the reform of the socialist economic system manifests that first to develop productive forces, the second to take public ownership as the main body and third to achieve common prosperity, which these three connect with each other and together constitute an organic whole.

Deng Xiaoping's reform theory on the reform of the socialist economic system proposes to take public ownership as the basis and the development of public ownership should be combined with the socialist productive forces.
Realize public ownership can prevent serious wealth gap so as to effectively realize the common prosperity of the people. The system taking public ownership as the main body fundamentally determines allocation of production relations and achieve distribution according to work to prevent polarization and achieve common prosperity.

Deng Xiaoping' reform theory and Chinese socialism reform complete each other. They both insist in and improve the socialist system under the premise of consisting in the socialist system ans are consistent with the specific systems in the development.

\section{Reform and improving specific system of so- cialism with Chinese characteristics}

The theory the reform is self-improvement and development of socialism in Deng Xiaoping's reform theory is not improvement and development of the original economic system, but complete overthrow of the existing economic system. Self-improvement and reform are dependent on the degree of reform. More thorough the reform is, more powerful the vitality of Chinese socialist system is and the more rapid productive forces develop. In the process of construction of socialist system with Chinese characteristics, socialism reform is not only an important basis for the reform of Deng Xiaoping theory, but also is important social ideological bases in the development of socialism.

In

the

Third Plenary Session of the 11th Central

Committee of the Chinese Communist Party, Deng Xiaoping put forward the four revolutionary propositions of modernizations and made a profound exposition of this revolutionary proposition . Reform is not adhering to the existing economic system and making simple repair, but the overthrow of the existing economic system and complete change and overthrow of the part restricting the productivity of existing systems, which is determined by the nature of the reform. Considering the reform as an important task in the socialist modernization construction is an 
important measure taken by the Party and leaders of the country in the new era and has the same nature with Chinese new-democratic and socialist reform. New Democracy and socialist reform is to reform the social system of the country and the reform begins from the old and specific system of country with a fundamental purpose of developing the productive forces and improve the socialist system. Establishment of the socialist system is common success of the new-democratic and the socialist revolution and this consolidation and development of the results need profound reform on the old system and establish new requirements in line with the socialist system. It is fundamental to liberate and develop productive forces to improve the socialist system, which is like the two major Chinese revolutions having a role in promoting the development of productive forces. Reform is not only to change the economic system, but also the political system, otherwise it will hinder the development of productive forces and modernization construction. In the South conversation, Deng Xiaoping discussed the reform is revolution and noted that we should liberate and develop productive forces under the premise of adhering to the socialist system as well as pointing out that the elaboration of Mao on the basic contradiction of socialism only see the advantage in line with the development of productive forces and neglect what is not suitable for the development of productivity,without liberate and develop productive according to the specific realistic condition.

\section{Conclusion}

Deng Xiaoping is not only the founder of the socialist road with Chinese characteristics, but also the founder of Chinese reform theory of the socialist system. Chinese reform theory of socialism with Chinese characteristics is a set of revolutionary theory and thinking which combines with the practice of Chinese reform and characteristics of the times under the guidance of Marxism and puts forward what is socialism and how to build socialism as well as coming up with a series of requirements and ideas on Chi- nese revolution, which reveals the victory of localization of Marxism in China again. For reform theory, Deng Xiaoping comprehensively and systematically points the way and practical method on Chinese 's reform and development, which is consistent with the purpose of Chinese socialist reform and put forward how to build socialism with Chinese characteristics on account of present status of backward in the process of reform. Deng Xiaoping' reform theory put forward higher requirements for the construction of socialism with Chinese characteristics on the objectives, the nature and direction of the reform and other aspects. It is demanded to adhere to the basic theory of Marxism in the process of construction of socialism with Chinese characteristics while while keeping the the unique flavor of the times and national identity of socialism with Chinese characteristics. Chinese reform theory has a characteristics of times and is formed under specific historical conditions to solve the problem of construction of Chinese socialism. Deng Xiaoping theory not only embody the theoretical spirit of localization of Marxism in China, but also combine with the spirit of times. Deng Xiaoping' reform theory is closely connected with Chinese reform and jointly promote the development and self-improvement of socialism with Chinese characteristics and.

Deng Xiaoping' reform Theory combines with of Chinese reform practice and achieves selfimprovement and development of the socialist system under the premise of insisting in socialist system to construct socialism with Chinese characteristics, promote the development of productive forces and make an important contribution to the socialist construction.

\section{References}

[1] Chen Shirun, Ou Xiaoyan, Revolution road, theory and spirit --Deng xiaoping's great contribution to Chinese reform [J], Explore, 2014,(03):4-8.

[2] Yan Shuqun, Deng Xiaoping's reform theory and construction of socialist system 
with Chinese characteristics $[\mathrm{J}]$, Gansu Theory Research, 2013,(01):59-64+1.

[3] Chen Yongjun, Deng Xiaoping's socialist market economical reform theory and Chinese reform strategy--written in Chinese's two-decade reform $[\mathrm{J}]$,Economic Issues in China, 1998,(04):8-16.

[4] Liu Jinghui, Deng Xiaoping's opening up theory and concepts of reform and innovation and social commitment in Chinese traditional thinking $[\mathrm{J}]$, Economic and Social Development,2008,(04):58-60.

[5] An Ran, Chinese reform practice and Deng Xiaoping's theory of socialist market economy $[\mathrm{J}]$, Liaoning University journal (Philosophy and Social Science Edition), 2000,(04):1-3.
[6] Li Mengyi, Road and theory:Deng xiaoping puts the foundation stone for socialism with

[7] Liu Chang, Deng Xiaoping's promotion of Research of Marxist era[D], Dalian Jiaotong University, 2013.

[8] Zheng Limin, Analysis on Deng xiaoping's thought about the social construction[D], Huaqiao University, 2014.

[9] Wang Zibo, Study on Deng Xiaoping's scientific reform idea[J], Journal of chongqing university of science and technology(social sciences), 2015,(01):93-98. 